\title{
Medico-legal Implications of Illegal Commercial Toxic Detergent "Prinso": An Autopsy Study
}

\author{
Konara Mudiyanselage Tikiri Bandara Gunathilake*1 $\triangle$ (D), Muditha Vidanapathirana² \\ ${ }^{1}$ Office of the Judicial Medical Officer, Provincial General Hospital, Ratnapura, Sri Lanka \\ 2 Department of Forensic Medicine, Faculty of Medical Sciences, University of Sri \\ Jayewardenepura, Sri Lanka.
}

\section{Introduction}

Time to time there are unusual commercial products appear in the market and they become epidemics of suicide. "Prinso/Pus kudu" is an illegal commercial detergent. This washing powder is marketed as two sachets; $12.5 \mathrm{~g}$ of oxalic acid and 1.2g of potassium permanganate. During past two years, there was an epidemic of suicide deaths due to ingestion of "Prinso" in Sabaragamuwa province, Sri Lanka.

\section{Material and Methods}

A descriptive cross-sectional study was conducted on all deaths reported for autopsy following self-ingestion of "Prinso" to Ratnapura Provincial General Hospital from January 2015 to December 2016. Autopsy findings were collected using a data collection form.

\section{Results}

There were 16 deaths. Ages ranged from 19 to 68 years. Most were young adults. Different brands of "Prinso" were used and relatives identified them as "Pus Kudu". It is tasteless and odourless. When 2 or 3 packs are taken, most $(n=11)$ died within 24 hours. According to autopsy, there were macroscopic and microscopic evidence of acute renal failure in five cases. Histopathology showed purple-brown stain in renal tubular cells in all cases.

\section{Conclusions}

It was concluded that due to attractive colour, mild corrosiveness and absence of taste or odour, "Prinso" is an ideal agent to commit suicide by ingestion. Adult males are more vulnerable and when more than one pack is ingested, death was almost certain and rapid. Rapid deaths could have been due to the direct or indirect effects of oxalic acid. Late deaths could have been due to acute renal failure by calcium oxalate. Since JMO comes to know the morbidity and mortality of such toxic products early, he/she should initiate safety measurements to prevent public harm.

Keywords: "Prinso/Pus kudu”, Availability, Toxicity, Mortality, Prevention

Copyright: @ 2017 with the Medico-legal Journal of Sri Lanka.

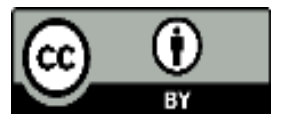

This is an open access article distributed under the terms of the Creative Commons Attribution License, CC BY 4.0 which permits unrestricted use, distribution and reproduction in any medium, provided the original author and source are credited.

Funding: None, Competing interests: None

Received: 10 November 2017

Accepted revised version: 20 March 2018

Published: 01 April 2018

(iD) https://orcid.org/0000-0002-8485-4550

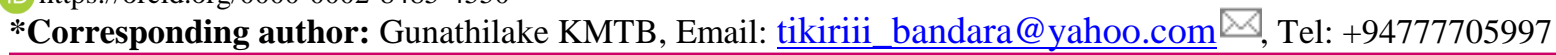

Cite this article as: Gunathilake KMTB , Vidanapathirana M. Medico-legal Implications of Illegal Commercial Toxic Detergent "Prinso": An Autopsy Study. Medico-Legal Journal of Sri Lanka, 2017;5(2):11-16

DOI: http://doi.org/10.4038/mljsl.v5i2.7358 


\section{Introduction}

According to the 'list of suicide rates by country' of World Health Organization (2012), Sri Lanka holds the third place. ${ }^{[1]}$ The commonest mode is selfingestion of agrochemicals. The other methods include plant poisoning, hanging, jumping into water etc. ${ }^{[2]}$ Suicide trends change according to the geographical areas of the country and season and time. For instance, in the north central province, oleander plant and agrochemicals are commonly used as they are available in the locality. In the areas of the rubber industry, acetic acid is ingested.

But time to time there are unusual commercial products appear in the market and they cause epidemics of suicide. "Prinso/Pus Kudu" is an illegal commercial detergent find in the market. This washing powder is marketed as two sachets, one consists of $12.5 \mathrm{~g}$ of oxalic acid $\left(\mathrm{H}_{2} \mathrm{C}_{2} \mathrm{O}_{4}\right)$ and the other has $1.2 \mathrm{~g}$ of potassium permanganate $\left(\mathrm{KMNO}_{4}\right)$ [3]. Further, it comes to the market in different brand names. It became popular as a remover of stains and fungus from clothes. Clothes are soaked in $\mathrm{KMnO} 4$ solution for two hours and then wash with dissolved Oxalic acid.

During past two years, there was an epidemic of suicide deaths due to ingestion of "Prinso" in Sabaragamuwa province, Sri Lanka. Judicial medical officer (JMO) identifies such illegal chemicals or agents early because he has to perform autopsies of all such deaths. Since it was an epidemic, the JMO also owes a duty to initiate measures to safeguard and protect the public. Therefore, it was decided to conduct a study on the deaths reported due to ingestion of "Prinso".

\section{Methods}

A descriptive cross-sectional study was conducted on all deaths that were reported for autopsy following self-ingestion of "Prinso" to Ratnapura Provincial General Hospital from January 2015 to December 2016. Diagnosis of self-ingestion was made based on the history, availability of used or unused packets, and other circumstantial evidence. Demographic factors, factors related to the incidence and the autopsy findings were collected using a data collection form. As secondary sources, Bed head tickets (BHTs), medical reports and police reports were also used. Permission of the Director of the Hospital was obtained prior to this study, which was based on already available routine postmortem data. IBM-SPSS statistical package 19.0 was used in the analysis of data. Anonymous data were used to maintain the confidentiality.

\section{Results}

According to the hospital data, there were more than hundred hospital admissions following self-ingestion of "Prinso" over 2 years from Jan 2015 to Dec 2016, and there were 16 deaths reported for post-mortem examinations. Ages ranged from 19 years to 68 years and most of them were young adults. They belonged to Ratnapura and the nearby police areas. The frequency distribution of sex, age and place of living are shown in Table 1.

Table 1. Frequency distribution of sociodemographic characteristics of deceased's

\begin{tabular}{llc}
\hline & $\begin{array}{l}\text { Socio- } \\
\text { demographic } \\
\text { factors }\end{array}$ & $\begin{array}{c}\text { Total } \\
\mathbf{( N = 1 6 )} \\
\mathbf{n}\end{array}$ \\
\hline Sex & Male & 10 \\
& Female & 06 \\
Age & $<20$ years & 00 \\
& $20-39$ years & 11 \\
& $40-59$ years & 04 \\
& $>60 \quad$ years & 01 \\
Place of & Urban & 08 \\
living & Rural & 08 \\
& & \\
\hline \hline
\end{tabular}

The different brands of "Prinso" used by the deceased were Vihaga, Bright light, Penso (Fig.1 and 2), Ever light and Diamond light.

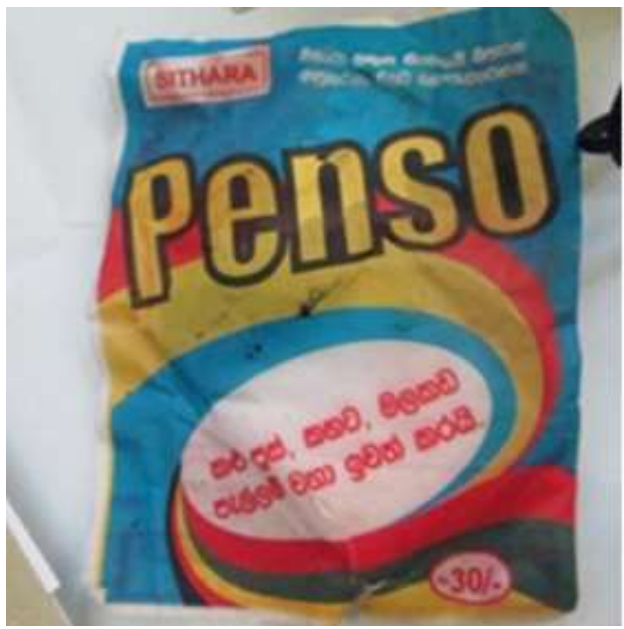

Figure 1. The front side of Penso 


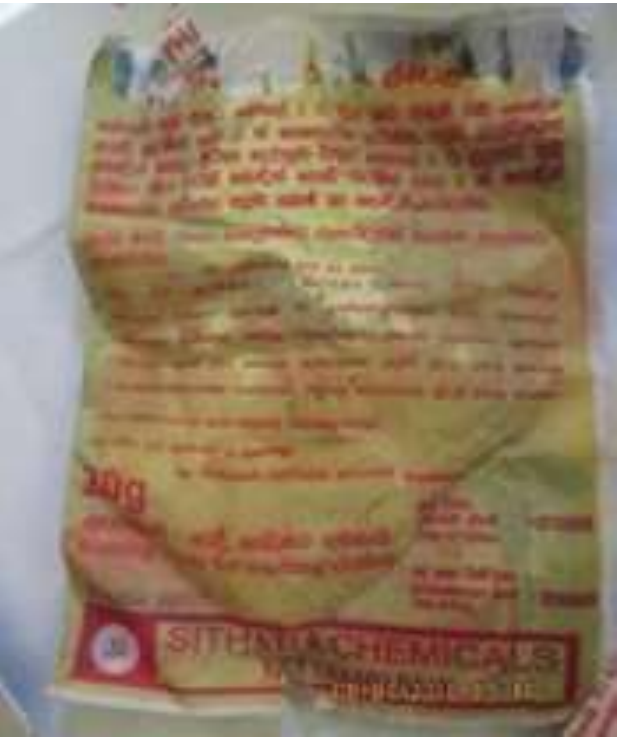

Figure 2. The reverse side of Penso.

In some products (Fig.3) no brand name or instructions were printed. Prinso" was available in two attractive violet and white colour sachets. The ingredients and their amounts had not been printed and relatives identified the products as "Pus Kudu".

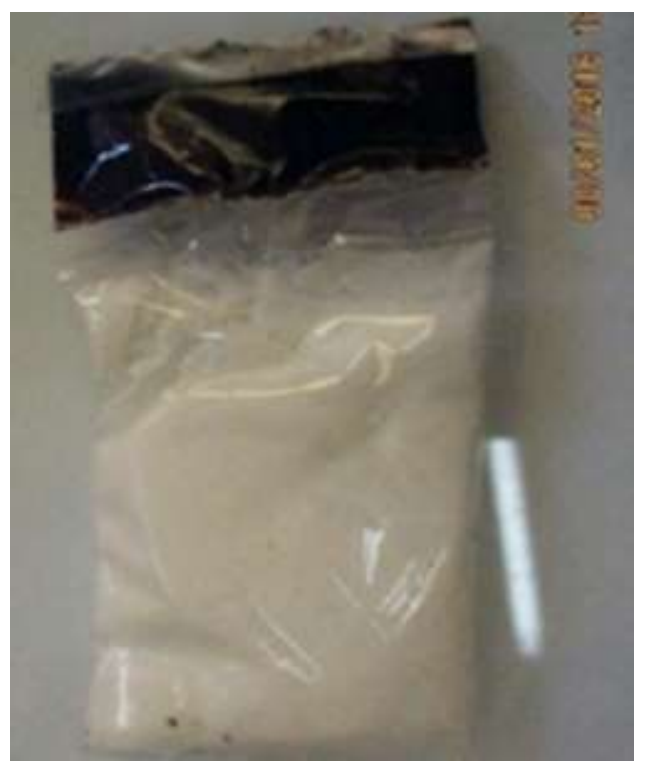

Figure 3. Two sachets with no brand name or instructions

The frequency distribution of factors related to the suicide incidents such as the number of packets ingested and time taken to cause death are shown in Table 2.
Table 2. Frequency distribution of factors related to the incident

\begin{tabular}{llc}
\hline \hline & $\begin{array}{l}\text { Factors related } \\
\text { to the incident }\end{array}$ & $\begin{array}{c}\text { Total } \\
\mathbf{( N = 1 6 )} \\
\mathbf{n}\end{array}$ \\
\hline Number of & One & 02 \\
packets ingested & Two & 08 \\
& Three & 06 \\
Time taken to & <one hour & 06 \\
cause death & 1-24 hours & 05 \\
& 1-14 days & 03 \\
& 15-30 days & 02 \\
& & \\
\hline \hline
\end{tabular}

The rapidity of the death based on the number of packets ingested is shown in Table 03.

Table 3: rapidity of death based on the number of packets ingested

\begin{tabular}{llc}
\hline \hline & $\begin{array}{l}\text { One packet } \\
\text { n (\%) }\end{array}$ & $\begin{array}{c}\text { Two or more } \\
\text { packets } \\
\text { n (\%) }\end{array}$ \\
\hline $\begin{array}{l}\text { Died within one } \\
\text { day }\end{array}$ & $00(00)$ & $11(79)$ \\
$\begin{array}{l}\text { Died after one } \\
\text { day }\end{array}$ & $02(100)$ & $03(21)$ \\
Total & $02(100)$ & $14(100)$ \\
\hline \hline
\end{tabular}

According to the Table 03, 79\% $(\mathrm{n}=11)$ of subjects who ingested 02 or more packs died within one day. However, none of the victims who ingested one pack did die within one day. Moreover, the 2 victims who ingested one pack died after one day. This could be a significant difference. Therefore, when two or more packs are ingested there was a higher chance of dying rapidly within one day.

According to the postmortem findings, there were no significant external features except mild cyanosis in two cases. Lungs were congested and, brain and heart appeared normal in all cases. There were macroscopic evidence of acute renal failure and microscopic evidence of renal tubular necrosis in five cases. Further, histopathology showed purple-brown stain in renal tubular cells in all cases. The frequency 
distribution of erosions and congestion of organs are shown in Table 4.

Table 4. Frequency distribution of postmortem findings

\begin{tabular}{llc}
\hline \hline & $\begin{array}{l}\text { Factors related to } \\
\text { the incident }\end{array}$ & $\begin{array}{c}\text { Total } \\
\text { (N=16) }\end{array}$ \\
\hline Erosions & $\begin{array}{l}\text { Mouth } \\
\text { Oesophagus and } \\
\text { stomach }\end{array}$ & 05 \\
& Present & 14 \\
$\begin{array}{l}\text { Congestion } \\
\text { of kidneys }\end{array}$ & Absent & 14 \\
& & 02 \\
$\begin{array}{l}\text { Congestion } \\
\text { of liver }\end{array}$ & Present & \\
& Absent & 08 \\
\hline \hline
\end{tabular}

The JMO informed relevant authorities and initiated several group discussions to control and prevent future deaths due to "Prinso/Pus Kudu".

\section{Discussion}

During postmortem investigations of suicides, the representatives of various investigative bodies have several social responsibilities such as explaining the death to the family members, attempting to reduce the risk of similar deaths in the future, and if applicable, apprehending the individuals who are responsible for the deaths. ${ }^{[4]}$ During the medico-legal investigations, other than legal responsibilities the JMO also has social responsibilities such as ensuring the public safety.

This study showed that "Prinso/Pus Kudu" is freely available under different brand names and the death is almost certain and rapid when ingesting more than one pack.

There were 16 suicide deaths over 2 years. The majority were males. However, in a study done in 2006-2007 in General Hospital, Matara showed a female preponderance. ${ }^{[3]}$

In this study, there were no deaths of children $(n=0)$. Similar to the study done in Matara [3], the majority $(n=11)$ belonged to young adults of 20-39 years of age. However, there was a 68 years old elderly death as well. Both urban $(n=08)$ and rural $(n=08)$ people committed suicide by ingestion of "Prinso".
Among legalized detergents or other toxic products such as pesticides and weedicides, the manufacturer follows certain precautions to prevent deaths due to self-ingestion. For example, registered washing powders such as "Surf excel" or toxic products such as paraquat, the brand name, ingredients and their amounts, registration number, address of the manufacturer, date of manufacture, date of expiry etc are printed in the pack or the label and most importantly, the warnings regarding toxicity are mentioned. In this study, it was evident that "Prinso" was identified by the relatives as "Pus Kudu" and was available in different brand names such as Vihaga, Bright light, Penso, Ever light and Diamond light. In some products, though incomplete, some instructions were printed (Fig. 1 and 2) but none of them showed the ingredients and their amounts. In some products, both the sachets were made of transparent polythene, and no brand name or instructions were printed (Fig. $3)$. Therefore, according to the "Consumer affairs authority act No. 09 of 2003", "Prinso" are illegal toxic washing powders in the market. ${ }^{[6]}$

There are certain natural barriers in the human to prevent ingestion of toxic substances. When a substance has an attractive colour, mild corrosiveness with no odour or taste, such features facilitate ingestion. Therefore, the legalized manufacturers of toxic products ensure to convert their products inedible. For example, paraquat is dirty greenish in colour and not attractive. Even if the colour was tolerated, when it reaches the nose, it gives a bad odour and will be repulsed. Even when it contacts the tongue, the bad taste and corrosive effects limit the ingestion and facilitate vomiting. However, in this study, it was evident that Prinso does not have any of those repulsive features. It was available in two attractive violet and white colour sachets. According to the study done in Matara on similar patients, it was evident that it is tasteless and odourless ${ }^{[3]}$ The autopsies did not reveal ulcers or perforations in the gastrointestinal tract but almost all $(n=14)$ had superficial erosions indicating that "Prinso" is a mild corrosive substance. Since "Prinso" has attractive colour, mild corrosive effect with no taste or odour, it is an ideal agent to commit suicide by ingestion.

Agrochemicals are expensive and are sold only in few shops. The shop owners know the benefits, as well as consequences of misuse and the retail outlets, do not even sell legalized toxic products such as agrochemicals freely and they further inquire about the purpose of purchase. Further, such agrochemicals have a specific brand name and are only used by farmers. Therefore, there are protective mechanisms among the public for toxic commercial products. 
However, since "Prinso" is a washing powder, anybody could buy it without further inquiry. It is freely available at any shop and is cheap (eg. Sri Lankan Rupees 30 a pack). In this study, it was evident that some brands of "Prinso" resemble the commonly available legalized non-toxic detergents such as Rinso. Therefore, Prinso further qualifies as an ideal agent to commit suicide.

Toxicologically also "Prinso / Pus kudu" has several qualities to be an effective poison. When the two sachet packs are mixed, the resultant becomes more toxic with high oxidizing effect. One pack of "Prinso" usually contains $12.5 \mathrm{~g}$ of oxalic acid and $1.2 \mathrm{~g}$ of $\mathrm{KMnO}_{4}$ [3]. When 2 packs are ingested together, there is $25 \mathrm{~g}$ of oxalic acid and $2.4 \mathrm{~g}$ of $\mathrm{KMnO}_{4}$. The toxic dose for oxalic acid is $15-30 \mathrm{~g}^{[7]}$ and for $\mathrm{KMnO}_{4}$ is $10 \mathrm{~g} .{ }^{[8]}$ When ingesting two packs together, though $\mathrm{KMnO}_{4}$ does not achieve its toxic dose, the oxalic acid achieves its toxic dose. Similarly, in this study, almost all $(n=14)$ had used two or three "Prinso" packs to commit suicide. Therefore, ingestion of one or a part of a pack has a less lethal effect. In this study, though there had been more than hundred self-ingestion admissions to the clinical wards, only 16 deaths were reported and the reason for survival of the majority could be due to ingestion of one or a part of a packet of "Prinso". Similar to a study done in Southern Province of Sri Lanka in 2009, when more than one packet was ingested, the death was almost certain $(\mathrm{n}=14)$ with less pain and suffering. ${ }^{[9]}$

In this study, the majority of deaths $(n=11)$ were within 24 hours of ingestion. According to the Table 03, when two or more packets are ingested there was a higher chance of dying rapidly within one day $(p=<0.05)$. The toxic dose of oxalic acid could have been reached easily when ingesting two or more "Prinso". Therefore, rapid deaths could have been caused by the toxicity of Oxalic acid together with the powerful oxidizing effect of $\mathrm{KMnO}$. Oxalic acid is a soluble salt. Once entered into blood it forms Calcium oxalate crystals and creates hypocalcaemia. This hypocalcaemia could cause rapid deaths due to depression of central nervous system, seizures, conduction defects and cardiac arrest. ${ }^{[5]}$ Another mechanism may be direct mitochondrial toxicity of oxalic acid leading to tissue hypoxia. ${ }^{[10]}$ In this study, there were 11 deaths within 24 hours of ingestion and those rapid deaths could have been caused by abovementioned mechanisms; the direct (toxicity on mitochondria) or the indirect (hypocalcaemia) effects of oxalic acid.
Calcium oxalate crystals deposit in kidneys and lead to congestion and kidney damage. Similarly, in this study, almost all $(\mathrm{n}=15)$ showed congestion of kidneys. In this study, 5 late deaths showed macroscopic and microscopic evidence of acute renal failure. The Calcium oxalate toxicity in renal tubules is a well-recognized mechanism of death among late deaths. ${ }^{[11]}$ Therefore, the late deaths $(n=5)$ could have been caused by acute renal failure due to renal tubular damage due to calcium oxalate.

It was obvious that Prinso is a highly lethal illegal washing powder dangerous to public health and cause a large burden to health care. In Sri Lanka, such products can be controlled by public health inspectors (PHI) but they mainly control food health and diseases among public. The National Dangerous Drug Control Board deals with narcotic drugs. The Consumer Affairs Authority mainly deals with quality of consumer products based on consumer protection laws. If any hazardous effect to the public, they are dealt under common law. Therefore, control of illegal toxic consumer products is not clearly belonged to anybody. Therefore, it was realized that necessity of an immediate control of this product and initiate measures to prevent future introductions to market. Therefore, in such circumstances, the JMO should initiate preventive actions in good faith, for the best interest of the public and prevent future morbidity and mortality. However, usage of mass media for awareness may be dangerous because awareness can increase copycat suicides. In this study, the JMO informed relevant authorities and initiated several group discussions to control and prevent future deaths due to "Prinso/Pus Kudu".

\section{Conclusions}

"Prinso/Pus Kudu" is an illegal toxic washing powder available in the Sri Lankan market. Since it is a washing powder, anybody could buy it without further inquiry. Since it has an attractive colour, mild corrosiveness with no taste or odor, it is an ideal agent to commit suicide by ingestion. Adult males are more vulnerable. The death was almost certain and rapid when more than one pack is ingested. Rapid deaths are possibly due to the direct or indirect effects of oxalic acid. The late deaths are possibly due to acute renal failure by calcium oxalate toxicity. Time to time, illegal toxic agents are introduced to the market. Since JMO comes to know the morbidity and mortality of such toxic products early, he/she should coordinate and initiate safety measures to prevent public harm. 


\section{References}

1. List of countries by suicide rate. Available from:

https://en.wikipedia.org/wiki/List_of_countries_by_suicide_rate (accessed on 11.12.2016).

2. Gunnell D, Fernando R, Hewagama M, Priyangika WD, Konradsen F, Eddleston M. The impact of pesticide regulations on suicide in Sri Lanka. International Journal of Epidemiology. 2007;36(6):1235-42.

Doi: http://doi.org/10.1093/ije/dym164

3. Munasinghe MAAK, Fernando WKBKM. The toxic laundry detergent powder, "Prinso", is gaining notoriety among villagers in and around Matara district. Sri Lanka Journal of Critical care. 2009; 1 (1): 29-31.

DOI: http://doi.org/10.4038/sljcc.v1i1.940

4. Eddleston M, Gunnel D, karunaratna A, De Silva Sheriff MH, Buckley NA. Epidemiology of intentional selfpoisoning in rural Sri Lanka. Journal of Psychiatry. 2005;187:583-4

DOI:http://doi.org/10.1192/bjp.187.6.583

5. Consumer Affairs Authority Act No. 09 of 2003. available from:

https://www.slideshare.net/maxwellranasinghe/introduction-to-law-relating-to-consumer-protection (Accessed on 02.02.2018).

6. CDC - Immediately Dangerous to Life or Health Concentrations (IDLH): Oxalic acid - NIOSH Publications and Products. cdc.gov. available from:

http://www.cdc.gov/niosh/idlh/144627.html

7. Korkut E, Saritas A, Aydin Y, Korkut S, Kandis H, and Baltaci D. Suicidal ingestion of potassium permanganate. World Journal of Emergency Medicine. 2013; 4(1): 73-4.

DOI: http://doi.org/10.5847/wjem.j.1920-8642.2013.01.014

8. Gawarammana IB, Ariyananda PL, Palangasinghe C, De Silva NG, Fernando K, Vidanapathirana M, Kuruppuarachchi MA, Munasinghe MA, Dawson AH. Emerging epidemic of fatal human self-poisoning with a washing powder in Southern Sri Lanka: a prospective observational study. Clinical Toxicology.2009;47(5):40711.

DOI: http://doi.org/10.1080/15563650902915320.

9. Michel J. Shkrum, David A. Ramsay. Forensic Pathology of Trauma, common problems for the pathologist. $1^{\text {st }}$ ed. Humana Press; 2007.

10. Cao LC, Honeyman TW, Cooney R, Kennington L, Scheid CR, Jonassen JA. Mitochondrial dysfunction is a primary event in renal cell oxalate toxicity. Kidney International. 2004;66(5):1890-900.

DOI:http://doi.org/10.1111/j.1523-1755.2004.00963.x

11. Konta T, Yamaoka M, Tanida H, Matsunaga T, Tomoike H. Acute renal failure due to oxalate ingestion. Internal Medicine. 1998;37(9):762-5.

DOI: https://doi.org/10.2169/internalmedicine.37.762 